\title{
LOVE OF LAND: NATURE PROTECTION, NATIONALISM, AND THE STRUGGLE OVER THE ESTABLISHMENT OF NEW COMMUNITIES IN ISRAEL ${ }^{1}$
}

\author{
Shai M. Dromi \\ Harvard University \\ Department of Sociology \\ 33 Kirkland St. \\ Cambridge, MA 02138 \\ shai.dromi@g.harvard.edu
}

\author{
Liron Shani ${ }^{2}$ \\ 1. Hebrew University of Jerusalem \\ Department of Sociology and Anthropology \\ Mt. Scopus 91905 \\ Jerusalem, Israel \\ liron.shani@mail.huji.ac.il
}

2. Massachusetts Institute of Technology

STS Program, Building E51-163

77 Massachusetts Ave

Cambridge, MA 02139

KEYWORDS: Nature, nationalism, sustainability, social movements, Israel, Jewish-Israeli settlers

This manuscript was published in final form as Dromi, S. M. and Shani, L. (2019), Love of

Land: Nature Protection, Nationalism, and the Struggle over the Establishment of New Communities in Israel. Rural Sociology. doi:10.1111/ruso.12274. The article is available at this link: https://rdcu.be/bsgej

\footnotetext{
${ }^{1}$ The authors are indebted to Eyal Ben Ari and Nurit Stadler for their input on this project. Rafi Grosglik, Matthew Lawrence, Timothy Malacarne, and Kari Norgaard provided valuable comments on previous versions of this paper. The research was supported by funding from the Shaine Center for Research in the Social Sciences and the Yad Ora fund at the Hebrew University of Jerusalem.

${ }^{2}$ Both authors contributed equally to this article and are listed alphabetically.
} 


\begin{abstract}
Although there is burgeoning research on environmental activism, few studies have examined the interrelationship between nationalism and nature protection in detail. This paper examines how groups manage the tension between national commitment and caring for the environment. It focuses on two opposing Israeli activist groups: a settler movement that aims to establish new communities in the fast-dwindling Israeli open expanses, and a "green" movement intent on preserving open spaces. Our observations, interviews, and textual analysis show that both groups believe themselves to be committed to the protection of nature, and that both groups see environmental responsibility as an integral aspect of their Zionist identity. However, the Israeli green movement sees abstaining from interventions in nature and adhering to sustainable development as Zionist because it preserves Israel for future generations. Conversely, the settler movement sees active intervention in nature — by building new communities, planting trees, and hiking — as the proper way to protect Israeli natural expanses and to maintain the livelihood of Israeli society. Our case demonstrates that, although environmental movements often aspire to universalism, local movements also interlace environmentalism and nationalism in ways that generate multiple (and even contradictory) interpretations of the appropriate way to care for nature.
\end{abstract}




\section{INTRODUCTION}

Although there is much research on the way environmental values disseminate onto specific nations, far less is known about the roles nationalist belief systems play in the local adoption and transmutation of environmentalism. In fact, much of the existing sociological work on nature protection has assumed that nationalism is unrelated to environmental values, except when political actors adopt environmental discourse to promote their underlying interests. Conversely, numerous studies have shown that local populations harbor elaborate systems of beliefs about nature protection (Dove 2006; Espeland 1998), but these studies have not explored how actors conceive of nature protection within the context of their national identity. However, groups may also adopt environmental ideas and practices into a broader nationalist cultural framework, thereby combining a sense of belonging to the nation with an imperative to preserve nature. Without a clear understanding of the lines actors and groups draw between their nationality and caring for nature, the literature on the spread of environmentalism misses a common aspect of environmental activism.

In this article, we ask the following questions: how do groups conceptualize the role of their nation in caring for the environment? how do they manage the tension between the global aspirations of environmental activism and their national belonging? To answer these questions, we use interview, observation, and textual data focusing on the deployment of environmental discourse in Israel in 2005-2014. Using these data sources, we identify how actors on both sides of the political map incorporate ideas about the protection of nature into broad conceptions of Israeli nationalism.

Specifically, we focus on two opposing activist groups, which have been central voices proffering claims about nature in Israeli public discourse in recent decades. The first is a group 
of environmental activists, whose green advocacy became prominent in Israeli public discourse starting in the 1990s. The second is a group of Jewish-Israeli settlers, who were evicted from Gaza during the 2005 Israeli withdrawal, and are working to establish new communities within Israeli borders. We examine a struggle between the groups over establishing a new community in the sparsely settled Lachish region in East-Central Israel. State authorities had previously planned to populate the region (Dunsky and Golani 1992), and the settlers were particularly interested in this area due to its rural characteristics. Green activists staunchly opposed this plan because the region is an ecological corridor that connects different habitats. Establishing new settlements there would pose great risks to local biodiversity. The two groups clashed over this issue between 2005 and 2009, both in formal settings such as committee meetings and procedural hearings, and in the public sphere.

The debates over establishing the new community provide an opportunity to examine how two opposing sectors in Israeli society view the relationship between building settlementstraditionally the marker of Israeli nationalism — and caring for nature. We follow Eliasoph and Lichterman's claim that collectives have specific "styles" that filter broad cultural representations (like "environmentalism" or "Zionism") into specific permutations that define good membership in the group (Eliasoph and Lichterman 2003). In our case, both green and settler activists drew on cultural notions of Israeli commitment to nature, but-through different group styles-interpreted what this might concretely mean in opposing ways. For the settlers, building new settlements was the proper ways to protect nature, and is a way to demonstrate their commitment to Israeli society and the Zionist project. Green activists saw new settlements as harmful to nature, and saw nonintervention as the only way to preserve Israeli nature for future generation and to thus express one's love for Israel and commitment to Zionism as they see it. 
Nevertheless, both groups conceptualized caring for the environment as a key expression of Israeli nationalism. Thus, across political lines, activists interlaced their perceptions of Israeliness and their understanding of nature protection, and their beliefs informed their subsequent activism and policy advocacy ${ }^{3}$.

Numerous authors have interpreted settlers' claims to environmental responsibility as simple legitimating tropes, voiced by their political leaders in order to endow legitimacy on their controversial project (Tal 2008, McKee 2016). Similar objections can be made about green activists who claim that they are Zionist, by interpreting their claims to national allegiance as a mere framing strategy. However, our findings show that — acceptable or not for other Israelis the settlers have developed a wide-ranging ideological framework according to which building new settlements is an imperative, both socially and environmentally. Their ideas about their commitment to nature far outstep their political activism and extend to other areas of their social life as well. Similarly, green activists voiced claims to Zionism in political contexts, but here, too, their perceived commitment to Israel's welfare and future extended far beyond their political activism and was embedded in their broader cultural world. Methodologically, we view the clash between the groups as what Michèle Lamont (2012) and others call a trial (épreuve), which is a historical point in which actors feel obliged to express the meanings a social arrangement or

${ }^{3}$ This article does not seek to evaluate the extent to which either party aligns with specific standards of environmentalism in any of its definitions. Instead, it points to the fact that regardless of their differences - both sides believe themselves to be highly committed to nature, and promote policies that reflect their beliefs. For discussion of the different historical definitions of environmentalism see Frank 1997 and De-Shalit 2000. 
process holds for them. In these situations, actors render their regularly taken-for-granted presuppositions about public morality observable. The fact that each side articulated stances on its commitments to nature and to Israel in the context of this specific debate does not mean that each side conceived of its stance for the sole purpose of furthering its interests then and there. While the specific focus on the new settlement provoked increased reflection on the "national environmentalist" aspect of each side's worldview, the opinions they articulated in interviews align with longer-standing themes within each group's broader cultural framework.

We follow Brubaker (1997) in seeing nationalism as “a heterogeneous set of 'nation'-oriented idioms, practices, and possibilities that are continuously available or 'endemic' in modern cultural and political life" (p. 10). While some scholars have assumed that nationalism constricts global awareness (Escobar 2008, Ram 1999), nationalism is a multifaceted cultural phenomenon that affects populations unevenly and does not necessarily evolve into chauvinism (Bonikowski and DiMaggio 2016). The meanings actors assign to the nation may include a commitment to global civil values, including a sense of responsibility toward the environment. Where the notion of national exceptionalism usually conjures up belligerent imperialism (and along with it a resistance to global influences) (Randeria 2007), it can also denote a sense of unique national responsibility for civil values, such as inclusivity, equality, and environmental commitment (Gorski \& McMillan, 2012; Gorski 2017).

Understanding that nationalism can mediate the deployment of ideas about caring for nature helps place contemporary debates over nature preservation projects in context, in the Middle East or elsewhere. Scholars in political ecology have grown increasingly critical of environmental movements due to their clash with local communities (Escobar 2008, Holt 2005, West, Igoe and Brockington 2006, Brydon 2006). These scholars have been particularly critical of the tendency 
of environmentalists and scientists to impinge on regional economies and social structures in the name of global values and environmental responsibility (Barnes 2014; Dove 2011; Randeria 2007). Understanding that nationalism as a belief system may be salient in articulating and disseminating notions of nature preservation can help devise future environmental initiatives that would be more acceptable for local populations. The findings from our case can help make sense of other cases where environmental groups struggle against treatments of nature that other groups find collectively meaningful. Such cases might include hunting (which hunters often believe to express national identity, see Egan 2014), rural farming (which is a common point of contention with locals, Gupta 1998), meat industries (in which farmers may see themselves as naturists despite their involvement in environmental degradation, Kessler, Parkins and Kennedy 2016), or fishing (which many communities see as essential to their identity, Walley 2004).

Because of the high political stakes attached to settlements in Israel, the case of Lachish became particularly visible in the public sphere, and thus made the dynamics of these clashes readily observable.

Importantly, environmental scientists have claimed that building residential communities in wildlife corridors like the Lachish region is ecologically destructive (Efrat 2006; Tal 2008). In Israel-Palestine, the question of establishing new Jewish-Israeli settlements is doubly controversial, as it involves not only environmental harm but also the dispossession of Palestinian and Bedouin populations from their lands (McKee 2016; Yiftachel 2002). However, the finding that pro-settlement actors believe themselves to be environmentalists sheds light on a key facet of their belief system, which needs to be considered when formulating future resettlement schemes.

\section{EXISTING RESEARCH ON NATIONALISM AND THE ENVIRONMENT}


Although there is burgeoning sociological literature on environmentalism, little attention has been given to the possible relationships between national identity and environmental practices. Instead, much of the research has seen environmentalism as related to globalization, rather than national sentiments.

For example, numerous studies have analyzed the spread of environmental policies in the context of declining state autonomy and the emergence of global markets (e.g., Schofer and Granados 2006). In particular, studies in world-polity have focused on the ways states gradually adopt environmentally responsible policies as they seek to appear legitimate in international arenas (Shorette 2012; Schofer and Hironaka 2005). Even though recent studies in this vein have also examined the nation-level factors that facilitate the adoption of such policies (Longhofer and Schofer 2010), the world-polity approach largely emphasizes the top-down diffusion of environmental values without attributing much significance to state-level conceptions of the nation and its role in protecting the environment. Instead, research in this area focuses on tangible signs of "national environmentalization” (Frank, Hironaka and Schofer 2000, p. 99), such as emissions policies, national parks, and local chapters of global environmental organizations.

Political sociologists and political scientists have taken a closer look at the nation-level dynamics that promote environmentalist agendas in domestic political systems. Studies focusing on "econationalism", which ties national self-determination to the protection of a national environment, have shown the strong role environmentalism played in nationalist politics in several Soviet states and elsewhere in the Eastern Bloc, as well as in the UK (e.g., Fowler and Jones 2005; Dawson 2000). However, in these study cases, alliances between nationalist and environmental parties were short lived and broke apart after achieving a shared goal, such as national 
independence or a favorable elections result. Other studies have shown how state actors employ environmental policies to greenwash discriminatory zoning policies, deflect political criticism, and promote neoliberal agendas (Anthias and Radcliffe 2015). Overall, research in this area mainly focuses on cases in which state or political actors align themselves with environmental agendas out of practicality rather than ideological commitment.

More recent sociological work has unpacked the cultural dynamics of the domestic dissemination and adoption of policies relating to nature. Sociologists have examined value diffusion mechanisms (Pampel and Hunter 2012), social movement activism (Vasi and King 2012), grassroots organizing (Bevington 2009), green-washing narratives (Aptekar 2016), and media effects on public environmental risk perceptions (Andrews and Caren 2010). Other studies have focused on the intra-national social and political conditions that facilitate support for environmental initiatives and movements (Rudel 2013), and demographic characteristics of environmental supporters (Mertig and Dunlap 2009). In particular, studies in social movement framing have demonstrated that cultural frameworks that identify environmental problems as pressing social problems are crucial in order to mobilize societies to act to alleviate them (Carmichael, Jenkins and Brulle 2012). Research in this vein has shown how social movements intertwine ethnic struggles with notions of ecological responsibility (Deutsch Lynch 1993) and draw on nationally-specific cultural codes to promote environmental activism (Kern 2010).

However, researchers in this area have said little about the extents to which popular nationalism may intertwine with environmental values and, at times, transmute them. This is despite the fact that much of the scholarship on cultural conceptions of the environment and nature sees them as embedded in group self-conceptions (Greider and Garkovich 1994). Specifically, scholars have shown that national belief systems often include particular notions of nature and its relationship 
to human society (Mukerji 1997). Justin Farrell (2015) demonstrates, for example, that Yellowstone National Park embodied a spiritual view of nature and its relationship with American identity. In a different way, Colin Jerolmack (2013) showed how Turkish-origin pigeon keepers in Berlin identify pigeons as sharing their Turkish identity and connection to

nature, and use them to carve out an immigrant space in Berlin. Other ethnographers have further demonstrated that communities often understand climate change through the lens of their national identity (e.g., Norgaard 2011; Jasanoff 2007). Thus, while studies of national identity and nature have demonstrated the varied ways in which the two are linked, there is little research about the ways different activist groups perceive of the relationship between their environmental commitments and their national belonging. The current study addresses this lacuna.

\section{DAta ANd Methods}

We follow Lamont and Swidler's methodological pluralism (2014) in using multiple methods while acknowledging the strengths and weaknesses of each. We draw on interviews, participant observations, and textual analysis to examine different aspects of group members' understanding of the environment and its protection, and its perceived relationship to Israeli nationality.

Interviews. In order to examine the logics group members invoke to frame their relationship with the environment, 84 semi-structured interviews were conducted: 36 with Israeli environmental activists and staff members at environmental organizations (e.g., activists, scientists, and executives), and 34 with settler leaders, and members of settlement and development organizations. The remaining interviews were conducted with state officials and related actors in the field. The interviews were conducted by the second author both before and after the establishment of the new settlement. Each interviewee was asked about their biographical and 
professional background, as well as their experience in their respective fields. The interview then continued in a life-story format, with the specifics of the struggle over the proposed settlement emerging from the stories. Finally, the interviewer probed specific events the interviewees raised to elicit what Allison Pugh calls schematic data — verbal and nonverbal cues such as jokes and metaphors that convey the framew orks actors use to view the topic under discussion—and honorable data - ways interviewees present themselves positively and compare themselves to others, which reveal the categories actors consider worthy (Pugh 2013). The interviews ranged between 30 minutes and two and a half hours, and usually took place at times and locations chosen by the interviewees themselves - often at their homes or work places, but at times at coffee shops or other public sites. The interviews were recorded and fully transcribed.

Observations. While the interviews provided important information about the ways each group views nature and Zionism, as well as the ways each group defines itself in relation to the other, observations helped demonstrate how these understandings inform group members practices in situ. Indeed, several scholars have recently pointed to potential disjoints between what individuals say and what they do (Jerolmack and Khan 2014), and the observations helped account for this issue. Observations were conducted in two types of sites: (a) meeting places between the factions, such as the waiting hall outside committee and court hearings, as well as public spaces where demonstrations and other meetings were organized; and (b) community events and tours of the region each group conducted individually, as well as meetings at the relevant planning institutions and parliamentary committees, and conferences relating to settlements and the environment. The meeting places between the groups revealed the terms group members invoke when confronting opposite-group members, thereby shedding light on the categories actors deem relevant to evaluate both nature protection and Israeliness. The 
community events, the tours, and the meetings demonstrated how each group maintain similar notions of nature protection and Israeliness when not confronted by their opposing group. The latter observations allowed us to evaluate the continuity between expressed opinions and concrete practices ${ }^{4}$.

Textual and visual data. We supplemented the interviews and observations by analyzing texts from protocols of meetings in planning institutions and parliament committees, articles and texts environmental actors produced, and additional documents such letters, and emails that actors from the field provided. In addition, we examined videos the settlers produced to promote their cause, and how they continued to frame the situation after the settlement was finally established, up until 2014. Much like the interviews, the textual and visual data demonstrated the categories each group has used to frame its relationship to the nation and to the environment.

Data analysis. We read the field notes and interview transcriptions and examined the visual data while coding recurring themes and constructing grounded theory categories inductively. In our initial analysis, references to the national meanings nature holds recurred in both groups, leading

${ }^{4}$ Part of the potential inequality between the researchers and the interviewees was alleviated due to the second author's background. On the one hand, having been raised in a small rural Southern Israeli township belonging to the settlement movement (albeit in a more left-wing variant) allowed him to reach an easier understanding with settler interviewees. On the other hand, his identity as a secular academic and deep acquaintance with the environmental field helped him interview like-minded environmental activists. For full information about the ethnographic method see Shani 2011; 2012. 
us to reread the material and to identified for each group the categories group members used as they described how they related to nature, to Israel or Israeliness, and to the opposite group. We elaborate below on those categories that were salient across the diverse interviewees from each group, despite age, gender, and positionality differences (we include specific information about each interviewee quoted (using pseudonyms) in Online Appendix 1).

\section{ProteCting NATURE AS AN EXPRESSION OF GOOD ZIONISM}

Early-twentieth-century Zionist attitudes toward the environment parallel the ethos that characterized the United States in colonial and post-independence eras, according to which the "newly found" expanses were effectively empty and waiting to be colonized (De-Shalit 1995). Zionist settlers and ideologues perceived historic Palestine as a vast and vacant space, and developed ideas about restoring ancient Jewish ownership of the land by taking possession over this space (Galai 2017). When the dust settled from the 1948 Arab-Israeli War, the ceasefire treaties, the mass displacement of Arab Palestinians, and the international recognition of the borders of Israel (the "Green Line"), Israeli leadership sought to establish its control over these newly acquired territories through ownership and physical presence (Feige 2009), as well as by transforming parts of the land into agricultural plots (Rabinowitz 1992). Government officials and Zionist leaders in the 1940s and 1950s described such development projects as serving not

only practical ends but also assisting in establishing Israeli collective identity (Orenstein, Tal and Miller 2013).

\section{Green activism in Israel}

In the early 1990s, environmental activists began challenging this long-standing ethos by advocating for sustainable development (Goodland 1995), based on balancing the uses of natural 
resources and nature's ability to renew itself (Alon-Mozes 2012). This new generation of activists has linked environmental and social justice (Tal, Leon-Zchout, et al. 2013), and tended to depict previous modes of environmental thought as traditional, outdated worldviews. Various Israeli environmental organizations have appeared since the 1990s, and their activism has affected the legal system (Tal 2008), planning authorities (Shmueli, et al. 2015), consumer patterns (Greenspan, Handy and Katz-Gerro 2012), education (Sagy and Tal 2015), policy, and politics. Activists have worked through environmental NGOs and think-tanks to impact civil society, with some actors endorsing the sustainability paradigm gradually entering state organizations like the Society for the Protection of Nature (SPN) and related state agencies 5 . Collectively, these activists are the "green" activists in our analysis.

While this "sustainability camp" has not been actively involved in political questions over settlements in the Occupied Palestinian Territories, one of the key issues it has tackled has been the establishment of new communities within Israeli borders and its effects on open spaces (Tal 2008). Sustainability advocates have pushed for already-existing towns to be augmented with new residences instead of creating new townships in order to reduce environmental impact. This issue became more pressing when Israel withdrew from Gaza and parts of the West Bank in 2005 (commonly known as "the Disengagement") and evicted all Jewish-Israeli settlers from these regions. The settlers were largely moved into temporary residences, where they awaited

\footnotetext{
5 There is an interesting parallel between the Israeli shift in attitude toward nature and history of the Wilderness Movement in the U.S. The latter movement has its roots in a nationalist ethos, but has gradually split into a conservation camp and a preservation camp, which respectively correspond to the older and newer approaches in Israel (see Sutter 2002).
} 
permanent resettlement by the state for several years in some cases, with many of them expressing the wish to establish new communities elsewhere.

\section{Post-Disengagement Israeli settlers}

The settlers, who form the second group in our analysis, occupy a very different socio-political position than the sustainability activists. Where the latter are predominantly reform/conservative or nonpracticing Jewish, most settler evictees subscribe to the religious-Zionist strand of orthodox Judaism. Many of them believe the active development and settlement in the region is a religious obligation, both within Israeli borders and in the Occupied Palestinian Territories (Aran 1991). While building new settlement within the pre-1967 borders remains perceived as a necessary and legitimate practice by the Israeli consensus (Rabinowitz 2003), establishing settlements outside these borders (particularly in the West Bank and Gaza) has become subject to a bitter public debate ${ }^{6}$.

${ }^{6}$ Israelis largely differentiate between traditional pre-Independence Zionist settlers (mityashvim), who established Jewish settlements primarily within the 1948 armistice borders, and the post1967 settlers who primarily settled in the Occupied Territories (mitnachlim). The latter groupto which the Gaza evictees belong - constitutes a distinct social movement that sees itself as the contemporary bearer of the Zionist traditions of establishing new settlements, and adheres to right-wing political views and, to large extents, to religious-Zionist Orthodox Judaism. We refer to "settlers" in this article as those who self-identify with the mitnachlim movement. For more details on mitnachlim see Feige 2009, Shani 2018b, Dromi 2014. 
The settlers perceived the 2005 Withdrawal from Gaza and parts of the West Bank, in which 25 settlements were dismantled and approximately 9,000 settlers were relocated, as highly traumatic (Feige 2009). It stood against a long-standing belief in the necessity of building and developing the region, as well as a self-perceived good citizenship and a sense of contribution to the nation through settling. With the Gaza Strip no longer accessible, the evictees doubled their efforts to establish new settlements in other regions, including within pre-1967 borders (Dalsheim 2011).

\section{The Lachish environmental corridor}

The location of one of the newly proposed community settlements was in the East Central Lachish region, near the Palestinian city of Hebron but within the pre-1967 Israeli borders. This region is characterized by a succession of open spaces - a rare commodity in central Israel — that transition from Mediterranean forests, woodlands, and scrub in the north-west to semi-arid land in the south-east. The region is unusually diverse in flora and fauna, and supports numerous species that are in danger of extinction. This high biodiversity is contained within a mere 173,000-acre region.

\section{FIGURE 1 ABOUT HERE}

Government plans to establish a rural township in the area have been in existence since the mideighties, as part of a plan to establish settlements alongside the border in order to maintain

Jewish dominance in the region (Dunsky and Golani 1992). However, these plans had stalled due to bureaucratic obstacles and environmentalist objections. Lachish forms an ecological corridor between different habitats, allowing uninterrupted wildlife travel and helping ensure biodiversity and reduce the negative effects of biosphere isolation. A new settlement, per environmental objectors, would destroy this corridor and have wide-ranging effects on the entire region. The withdrawal from Gaza and the demand of the evictees to establish new settlements provided the 
planning authorities with the leverage to push these plans forward. Since establishing new settlements within Israeli borders is largely unproblematic in Israeli public opinion (Rabinowitz 2003), environmental organizations had little success in recruiting Israeli anti-occupation activists to their cause. Despite a four-year legal battle that reached the Supreme Court, construction began in 2009 and 450 residents were already housed in the new settlement by 2015.

\section{Settlers and green activists compared}

Across the interviews, observations, and texts, settlers and green activists affirmed that nature should be protected by any means necessary, and presented themselves as the true guardians of the environment. Members of each group cited specific practices they undertake as a group that demonstrate their commitment to the environment and their love of their country, and contrasted themselves to the opposite group. Table 1 summarizes the main differences between the groups.

\section{TABLE 1 ABOUT HERE}

The stark symmetry between the two parties was most evident when the two groups came together in the same spaces, where each group used terms and logics that were aimed at contradicting the other group. One prominent example was a September 2008 hearing the National Committee for Planning and Construction held to decide whether to establish the new township. Representatives of both sides were asked to step outside, and found themselves waiting together for updates in the hallway. This was one of the most loaded encounters between the two groups: on the one side, settlers attempted to demonstrate their environmental commitment by wearing green shirts saying "Marsham [the proposed settlement] is my natural home." On the other side, environmental organization activists attempted to highlight their Jewish-Israeli national attachment by handing out stickers quoting the biblical verse "to cultivate 
and watch over it" [in reference to God's Genesis injunction to Adam in the Garden of Eden] or with the idiom "I have no other country", expressions which are usually associated with the right wing of the political map.

One of the young settlers, Adva - a Gaza Strip evictee and mother of two - turned to one of the environmental activists and asked, “why are you so against us? Why do you fight us?" Yonatan, an ecology student and one of the surveyors of Lachish, responded: "We're not against you; we're for you. We understand what you've been through, but we're against establishing a community in that specific place. It's a sensitive area." Adva continued: "What's sensitive about it? Were you there? There's nothing there. No trees and almost no plants. It's a wilderness. I know. We hiked there." An older and somewhat more aggressive environmental activist, an ecology professor, jumped in: "You have no idea what you're talking about. It's an important ecological corridor. There are many species living there, butterflies, reptiles, and rare vegetation. The fact that you didn't see elephants there doesn't mean it's not a sensitive spot...."

The exchange becomes heated and Adva's husband, Udi — an educator — joins the debate: "So for a measly butterfly you abuse us like this? You've seen what goes on across the fence [on the Palestinian side] — you can be sure there are no butterflies there. That's the problem with all of you. You care about butterflies and not people...." Amit, an environmental science professor and a green activist, joined in: “Oh come on, you're not serious. Of course we care about both people and butterflies. You don't have to settle there. You can settle in one of the towns that already exist. We don't have to establish a new township for each group...."

Yonatan, the environmental activist, tried to calm things down and turns to Adva and Udi, who were joined by two other settlers: “That's what the Bible says, doesn't it? 'to cultivate and watch over it'? So you have to care for butterflies just like you care about people, no? isn't that what's 
written?" However, Amit isn't done yet: “But nature doesn't interest you. You only want to establish a settlement against the Palestinians, no? That's all you care about in the end." Udi is flustered: "But you ['green' activists] also don't care about nature. You only care about hurting us because we're settlers. You've forgotten what it's like to be Zionist. To be-“

The argument was then cut short by a security guard, demanding silence in the hallway.

Each side was compelled to justify its side by drawing on the language of the other side - the settlers explained how they are lovers of nature, and the environmental activists asserted that they are connected to the state, to Judaism, and to Zionism. As Eli, a member of the settlement group, recalled in a subsequent interview: "How is it that I, who all my life saw myself as 'green' and a lover of nature, suddenly became the enemy of nature?"

While direct conflict places provided ample examples of actors highlighting the aspects of their collective identity they believed were environmental and "truly" Israeli, personal interviews and observations of each group separately showed that group members articulate similar sentiments when not directly confronted by the opposite group.

\section{SETTLER 'ENVIRONMENTALISM': LOVE OF NATURE THROUGH INTERVENTION}

The conflict over the new settlement came at a time when the settlers, only recently relocated from Gaza, were experiencing considerable uncertainty with relation to the state and to their own community (Dromi 2014). They saw the establishment of the new settlement as potentially recovering their relationship with the greater Israeli society and reaffirming their ideology. Establishing a new rural community would also allow them to reconnect to the landscape they had lost when they were removed from Gaza. 
Being "green" settlers and loving the country

As part of the broad view that human culture holds the key to the preservation of nature (Shani 2018a), many settler interviewees held that Israeli nationalism is, in itself, a form of nature preservation. Accordingly, they saw establishing new settlements in previously uninhabited regions (or in those previously held by Palestinians or Bedouin) as both a Zionist and an environmentalist practice. 'I am 'green' and I love the country, and part of the deal with establishing new settlements is also taking care of nature", said Dror, an evicted settler. "This means also taking care of Zionism, and keeping the vision alive... we're a small country... we have more migrants to absorb, and we have to build new settlements. This is not inflicting harm on nature - this is the nature of our nation" (Dror, 2008, Shekef).

The settlers contended that establishing a new settlement within internationally recognized borders would help them gain public legitimacy among Israelis who oppose the occupation. They presented themselves as bearing a responsibility to lead other Israelis to settle in sparsely populated areas like Lachish. In this, they saw their work as reconnecting to a pre-independence form of Zionism that emphasized land appropriation and rural, communal living. Settlers talked about building the new township in Lachish as a step toward revitalizing this strand of Zionism in Israeli society ${ }^{7}$. Once the new community in Lachish was established, residents dubbed it as the "heart of Israel's new frontier"s.

${ }^{7}$ The idea of contributing to Israeli society through settling is a staple of settler ideology, see Aran 1991, Feige 2009.

${ }^{8}$ https://www.youtube.com/watch?v=VHH6GcYVmb4 [accessed August 8, 2017]. 
Settler interviewees often differentiated between Israeli and their Palestinian and Bedouin neighbors by claiming that the latter care little about nature: "without a [Jewish] population here, nature will also be harmed because the Bedouin don't ask for permission from you, or me, or the government, or the Society for the Protection of Nature. They just do whatever they want, wherever and as much as they want to" (Eli, 2008, Shekef). In statements such as these, settlers established clear symbolic boundaries between Jews and non-Jews, based on environmental sensibilities, and between settler Israelis and "green" Israelis, based on perceived care for Israeli nature and society. As existing literature has shown, the Zionist imaginary has drawn on notions of historical Jewish sovereignty and exclusivity on the land and has othered non-Jewish populations (Gutkowski 2018, Yiftachel 2002). The settler certainty about Palestinian and Bedouin practices extends such othering into the realm of environmental sensibilities.

\section{Loving the land through intervention}

Settlers intertwine Zionism and caring for the environment in a long-standing practice related to settling: tree planting. Eli, a settler, described his love of nature as "planting trees, and in taking care of them - not uprooting but preserving..." (2008, Shekef). In an interview, the head of the planning authority for the settlements described his vision for the disputed Lachish region: "there is plenty of land here that can be cultivated into fields... we can plant trees here... they [the secular 'green' movement] don't get that if there will be people here, and development, there will be an environment to take care of" of" (Shlomo, 2009, Shekef). While scholars have pointed to the role of planting in creating a sense of place and in giving a community's relationship to nature a material expression (Muehlmann 2012), tree planting in Israel-Palestine has an intertwined ethnic-national aspect. This seemingly benign practice not only marks territories as 
Israeli, but also blocks previously-expelled Bedouin tribes from resettling (Abufarha 2008; Braverman 2009), and introduces a nonnative species - primarily pines - to the region.

Settlers were not only proud of the settlements and tree-plantings they spearheaded, but also spoke of an intimate knowledge of the landscape, which they saw as another marker of their Zionism and their commitment to nature. A key way they could demonstrate this knowledge was through hiking, a prominent practice among Zionists that dates back to the establishment of their movement (Ben-David 1997). Hedva, an evicted settler living in temporary housing, described hiking as a way of cultivating an awareness to the importance of protecting the environment. "Go to our [religious-Zionist] schools and go to other [secular] schools and see who really takes care of the environment. This is because people like me were raised to love the land through my feet, by hiking" (2009, in Shekef). Possessing an intimate knowledge of nature also figured strongly in the various community activities the evictees organized. As part of a holiday celebration the second author attended, one of the main attractions was local flower identification contest, and a similar activity took place during a community hike in the Lachish area, where the new settlement was planned. Settler interviewees claimed that most members of the Nature and Parks Authority hiking club are religious-Zionist, and objected to what they believe is a prevailing view, that religious Jews dislike nature.

Like hiking and tree planting, settlers ascribed both national and environmental meanings to the practice of building new communities. Describing the establishment of the new Lachish settlement as direct continuation of early-twentieth-century Zionist projects, settlers described it as contributing to state security and to social harmony with nature, and as revitalizing JewishIsraeli values in society. Promotional material published both before and after the community 
was established presented the settlement as ecologically responsible and harboring deep connections to the local environment ${ }^{9}$.

\section{"Environment is a very lefty thing, pardon the expression"}

Settler interviewees differentiated themselves sharply from anti-settlement environmental advocates, who they perceived as being motivated by a left-wing, pro-Palestinian agenda, rather than being truly dedicated to nature. The head of a local council complained that "you never hear objections when a Bedouin town is established. They [environmental activists] are conflating the environment with centrist and leftist political worldviews" (Shmulik, 2009, in Jerusalem).

In their interviews, settlers theorized about the hidden motivations they believed green activists harbor. Ariel, a settler activist leading a movement to establish the new settlement in the Lachish region, claimed that "Environment is a very lefty thing, pardon the expression." According to him, green activists "don't talk about what ties people to their land. Environment is their thing, and the land is not part of their values." By contrast, "for the settlement movement [land] is a value." Settlers thus saw the "green" movement as taking a politicized and disingenuous stance toward nature because they did not express similar objections to development in non-Jewish areas. "...All through the meetings about establishing a new settlement we told them that on the other side of the fence, [the Palestinians] destroy nature, so the Greens told us that they can't control that...", Ariel protested (2008, Amatzia). Settler interviewees thus presented themselves

\footnotetext{
${ }^{9}$ See, for example, an English-language video settlers posted in 2014 https://www.youtube.com/watch?v=VHH6GcYVmb4 [accessed August 1, 2017].
} 
as truly caring for nature, in contrast to the sustainability advocates who they saw as politically motivated.

\section{GREEN ACTIVISM: LOVE OF NATURE THROUGH NONINTERVENTION}

The settlers, through their interventionist approach, connected building new settlements (along with practices such as hiking and tree planting) with protecting the environment. By contrast, green activists contended that nonintervention in nature and conservation of open spaces is Zionist, and thus serves future Israeli generation. Their prevalent stance is that Israel should direct its resources toward urban renewal projects and toward the expansion of existing towns, and place the Gaza evictees there, instead of establishing new settlements (Tal, 2008, Orenstein, Jiang and Hamburg, 2011).

\section{Old vs. New Zionism}

When it came to the new settlement for the Disengagement evictees, green activists took issue not only with its very establishment but also with its remote location. An early Zionist reasoning for dispersing settlements across vast territories had been that land can be collectively owned and its borders can be defined only through the presence physical of Jewish population (Shani 2018a, Rabinowitz 2003).

But Green activists claimed that land appropriation and boundary-making by way of settlingwhich they knew was still powerful among settlers and decision makers - is no longer a valid approach. They observed with concern that the controversial withdrawal from Gaza, and the resultant call among right-wing circles (and some government agencies) to reinvigorate new settlement-building, was bringing new life into this worldview. "The rural settlement project hasn't died out, and when it gets backwind from the Disengagement ... we get the same narrative 
back — grasping the land, reinforcing settlements alongside the borders, Arabs against Jews, ..., what we call, Old Zionism" (Nadav, 2009, Be'er Sheva).

Speakers were resentful of settlers for not heeding their environmental logic. During one of the court hearings of an environmentalist appeal against the approval of the plan to establish the settlement in Lachish, an elderly settler representative stood up and shouted at Yehonatan, one of the younger environmental activists: 'I'm 'greener' than you! I was planting trees before you were born!" Several days later, in one of their field surveys, Jonathan recounted the story to the second author. "How will I explain to him that planting trees in Israel is not green? That it ruins nature, the habitats, and the landscape?" he lamented (Yehonatan, 2009, Jerusalem).

Even though most interviewees claimed that their activism is independent of the broader Israeli public debate over the future of the Occupied Territories, most of these activists subscribed to left-wing ideologies, and the party most of them supported was a decidedly left-wing party ${ }^{10}$. A key part of the platform of this party has been New Zionism. As articulated by one party member, "all of us love the Land of Israel, but ... maybe true [new] Zionism means preventing the establishment of new and harmful settlements, saving state funds, and strengthening existing weak settlements that are yearning for these resources and for new residents who will bring new life into their veins?" (Han 2008). The Deshe Institute (an SPN affiliate) published a 2007 public statement on the Lachish development plan, where they contended that "New Zionism means adopting a respectful attitude toward the appearance of this country,... [and] preserving the

${ }^{10}$ For more on the political leanings of environmental activists in Israel see Ram 1999 and DeShalit 2000. 
landscape for those who come after us. Lachish...provides us with an opportunity to apply this approach..." (Deshe 2007). As one activist put it in an op-ed: "whoever fights to protect every inch of the state's lands - from contractors, from polluters, from those with political interests, and also from tiny groups of settlers who each desire a hill for themselves - is the real Zionist" (Lavie 2008).

\section{Counting and cataloguing for Zionism}

In contrast to the settler practices of dominating the landscape through tree planting and hiking, environmental activists work to control the land through scientific knowledge instantiated by counting and cataloguing (Lynch 1988; Muehlmann 2012). A key practice by which ecological knowledge is generated is through field surveys. Surveyors divide a region into smaller units, and tour each in order to map, measure, and tag all flora and fauna. They use these data to categorize each unit according to its vulnerability, in order to inform authorities of the potential effects of development there. In one survey, the second author accompanied five volunteer surveyors as they scrutinized a unit in Lachish and registered each bush, tree, and living thing they recognized, including birds. The volunteers explained that data about the richness and diversity of the field site will discredit the settlers' claims about the area. Amir, one of the volunteers, said: "I don't know how they [the settlers] can say that [there is no severe harm to nature] after hearing expert opinions, and the research findings that show the influence of establishing new townships in this area. How can they say that doesn't exist?"

Green activists attached national meanings to this data and its employment in their committee and legal work. Representatives of the SPN used these data when serving in advisory roles in the various Israeli planning authorities and filing objections. During a recess from one of the court hearings in the motion environmentalist NGOs filed against establishing the new settlement, 
$\mathrm{Na}$ 'ama - an environmental activist and one of the petitioners - said to the second author: "Did you hear their claims? About how Zionist they are and how much they love the country and how that means they have to settle [in Lachish]? What nonsense is that? Am I not Zionist? Do I not love this country?" Liat, another environmentalist NGO staff member, joined in: “I'm sick and tired of them [the settlers] taking ownership of the word 'Zionism'. Zionism for me is loving my country, and I'm totally there, but you don't have to destroy nature in order to love this country you have to do the opposite!"

\section{Not bigots, but dedicated to Israel}

In emphasizing their commitment to Israel, green activists resisted being labeled "post-Zionist." The term "post-Zionist", originally coined to refer to a scholarly reappraisal of official and commonly held Israeli historiography, has turned into a derogative for much of the right-leaning Israeli public over the 1990s and carries the connotation of disloyalty to the nation (Ram 1999). This label has been applied most commonly by conservative and right-wing speakers to movements they identify (justifiably or not) as far-left. Interviewees expressed indignation at the settlers' claims that they are bigoted. Nirit, a planner in one of the environmental NGOs, claimed: "I'm tired of the [settlers'] claim that we're only picking on Jews and not Bedouins. What goes on with the Bedouin is illegal building ... but that's still within the purview of the law and its enforcement... But establishing a new township is a government decision, so we're trying to change that decision; to influence decision makers and the public."

Thus, in interviews, in clashes with the settlers, and through practices such as field survey and legal and bureaucratic action, green activists linked their conception of nature preservation to commitment to the welfare of Israel. They framed their activities using their reading of Zionist ideology as prescribing nonintervention in nature. 


\section{DISCUSSION}

The findings show that nationalist cultural frameworks can support notions of environmental commitment and vice versa. Both settler and green activists perceived their love of nature and love of country as intertwined. At the same time, the findings demonstrate that the concrete meanings of "environmentalism" can differ dramatically between groups. Through their different group styles, one side interprets environmental responsibility as nonintervention in nature, whereas the other side believes an active involvement in and appropriation of nature is the way to preserve it, generating radically different "cultures in interaction" (Eliasoph and Lichterman 2003). While existing studies have shown how the national is mediated through the environment and the environmental (e.g., through the cultivation of nationally symbolic gardens or parks Mukerji 1997, Pyne 1998), additional work is needed to examine this process of the social movement level and to capture how group styles bring these notions together.

While students of environmental movements often see nationalism as either antagonistic or irrelevant to such local notions of environmentalism (Schofer and Hironaka 2005), our findings suggest otherwise. The analysis highlights the need for sociologists studying the spread of environmental norms and sensibilities across borders to take account of the multiple ways in which actors may interpret abstract notions of environmental responsibility. While in some cases communities may identify the proper ways to care for the planet in practices such as establishing natural parks, refraining from building in open spaces, and adhering to sustainable development, in other cases communities may develop very different ideas about caring for nature. Thus, the settlers agree with the green activists that caring for nature is very important, but they manifest this belief in practices that are widely agreed to be detrimental to nature. Scholars examining the global diffusion of environmentalism elsewhere (e.g., Longhofer and Schofer 2010, Shofer and 
Granados 2006) would benefit from greater attention to the nation-level cultural frameworks that facilitate, modify, or dilute the adoption of global environmental models.

Our study also highlights the need to examine how environmental and national beliefs integrate into group culture, without presupposing that actors use them to promote underlying political interests. There has been a tendency among sociologists to assume that environmental discourse allows nationalist groups and organizations to greenwash their true interests (e.g., Galai 2017, Rabinowitz, 1992). By examining activists both at times of direct confrontation and in their daily lives, our research challenges this assumption. Instead of opportunism, we find continuity between settlers' stated positions about nature as they countered green activists and settlers' practices and cultural life in their own communities. Similarly, while settlers have accused green activists of "post-Zionism", our findings show that green activists profess a commitment to Israel even when not in confrontation with opposition groups. We suggest that additional attention to the continuity and difference between activists' on-stage and off-stage performance can help nuance existing arguments about their commitments. On a more general level, our findings support the claim that nationalism may include a sense of pride in a perceived national commitment to universal causes such as environmentalism or human rights (Gorski 2017, Gorski and McMillan 2012). Social movements scholars working on other types of movements (e.g., human rights, humanitarianism, social justice) would thus benefit from examining how beliefs about their nation mediates them.

This study also underscores the findings of existing research of Israeli expansionism (e.g., Alatout 2006; Braverman 2009) by showing that settlers and some Israeli policy makers understand the establishment of new settlements as an act that contributes to the protection of nature. One of the key justifications the settlers offered for the need to develop open spaces was 
the claim that Palestinians and Bedouins have no environmental sensibilities, and would destroy the landscape if Jewish-Israelis would not intervene. Understanding the salience of these justifications in settler circles sheds important light on the ongoing disownment of Bedouin and Palestinians from their lands.

Our research is limited by the fact that it focuses on one out of many struggles over land ownership, development, and environmentalism in Israel-Palestine. While the claims made by green and settler activists in our case resonate with claims made in other struggles, a systematic expansion of this study using additional research methods, as well as comparison to other cases, is necessary in order to determine the extent to which the notions presented here are prevalent in broader Israeli society. Further research is also necessary to include the corresponding Bedouin and Palestinian narratives about nature preservation in the region and the effects of the settlement project on the environment. These findings may help push forward more acceptable policies in Israel, or conversely help pursue justice for the populations affected by the settlement project via international routes.

\section{BIBLIOGRAPHY}

Abufarha, Nasser. 2008. "Land of symbols: Cactus, poppies, orange and olive trees in Palestine." Identities 15 (3): 343-368.

Alatout, Samer. 2006. "Towards a bio-territorial conception of power: Territory, population, and environmental narratives in Palestine and Israel." Political Geography 25 (6): 601-621.

Alon-Mozes, Tal. 2012. "Ariel Sharon Park and the emergence of Israel's environmentalism." Journal of Urban Design 17 (2): 279-300.

Andrews, Kenneth T., and Neal Caren. 2010. "Making the news: Movement organizations, media attention, and the public agenda." American Sociological Review 75 (6): 841-866.

Anthias, Penelope, and Sarah A. Radcliffe. 2015. "The ethno-environmental fix and its limits: Indigenous land titling and the production of not-quite-neoliberal natures in Bolivia." Geoforum 64 (1): 257-263.

Aptekar, Sofya. 2016. "Gifts Among Strangers: The Social Organization of Freecycle Giving." Social Problems 63 (2): 266-283. 
Aran, Gideon. 1991. "Jewish Zionist fundamentalism." In Fundamentalism Observed, edited by Martin E. Marty and Scott R. Appleby, 265-344. Chicago, IL: Chicago Univ. Press.

Barnes, Jessica. 2014. Cultivating the Nile: the everyday politics of water in Egypt. Durham, NC: Duke University Press.

Ben-David, Orit. 1997. "Tiyul (hike) as an act of consecration of space." In Grasping land: Space and place in contemporary Israeli discourse and experience, edited by Eyal BenAri and Yoram Bilu, 130-143. Stony Brook, NY: SUNY Press.

Bevington, Douglas. 2009. The rebirth of environmentalism: Grassroots activism from the spotted owl to the polar bear. Washington, DC: Island Press.

Bonikowski, Bart, and Paul DiMaggio. 2016. "Varieties of American popular nationalism." American Sociological Review 82 (5): 949-980.

Braverman, Irus. 2009. "Uprooting identities: The regulation of olive trees in the Occupied West Bank." PoLAR: Political and Legal Anthropology Review 32 (2): 237-264.

Brubaker, Rogers. 1997. Nationalism reframed: Nationhood and the national question in the new Europe. Cambridge, MA: Cambridge University Press.

Brydon, Anne. 2006. "The predicament of nature: Keiko the whale and the cultural politics of whaling in Iceland." Anthropological Quarterly 79 (2): 225-60.

Carmichael, Jason T., J. Craig Jenkins, and Robert J. Brulle. 2012. "Building environmentalism: The founding of environmental movement organizations in the United States, 19002000." The Sociological Quarterly 53 (3): 422-453.

Dalsheim, Joyce. 2011. Unsettling Gaza: Secular liberalism, radical religion, and the Israeli settlement project. New York: Oxford University Press.

Dawson, Jane I. 2000. "The two faces of environmental justice: Lessons from the eco-nationalist phenomenon." Environmental Politics 9 (2): 22-60.

De-Shalit, Avner. 1995. "From the political to the objective: The dialectics of Zionism and the environment." Environmental Politics 4 (1): 70-87.

De-Shalit, Avner. 2000. The environment: between theory and practice. Oxford and New York: Oxford University Press.

Deshe. 2007. "The development plan in Lachish." Deshe Institute. April 1. Accessed August 4, 2017. http://www.deshe.org.il/_Uploads/dbs_AttachedFiles/Lachish.pdf.

Deutsch Lynch, Barbara. 1993. "The garden and the sea: U.S. Latino environmental discourses and mainstream environmentalism." Social Problems 40 (1): 108-124.

Dove, Michael R. 2006. "Indigenous people and environmental politics." Annual Review of Anthropology 35: 191-208.

- 2011. The banana tree at the gate : a history of marginal peoples and global markets in Borneo. New Haven, CT: Yale University Press.

Dromi, Shai M. 2014. "Uneasy settlements: Reparation politics and the meanings of money in the Israeli withdrawal from Gaza." Sociological Inquiry 84 (2): 294-315. 
Dunsky, Nachum, and Yehonathan Golani. 1992. "'The Stars Plan' - 'The Hills Axis'." In Planning and housing in Israel in the wake of rapid changes, edited by Yehonathan Golani, Sofia Eldor and Meir Garon, 83-96. Tel Aviv: R. \& L. Creative Communications.

Efrat, Elisha. 2006. The West Bank and Gaza Strip: A geography of occupation and disengagement. London and New York: Routledge.

Egan, Sarah. 2014. "National identity and cultural resonance in English foxhunting movements." National Identities 16 (1): 1-20.

Eliasoph, Nina, and Paul Lichterman. 2003. "Culture in interaction." American Journal of Sociology 108 (4): 735-794.

Escobar, Arturo. 2008. "Whose knowledge, whose nature? Biodiversity, conservation, and the political ecology of social movements." Journal of Political Ecology 5 (1): 53-82.

Espeland, Wendy Nelson. 1998. The struggle for water: politics, rationality, and identity in the American Southwest. Chicago: University of Chicago Press.

Farrell, Justin. 2015. The battle for Yellowstone: Morality and the sacred roots of environmental conflict. Princeton, NJ: Princeton University Press.

Feige, Michael. 2009. Settling in the hearts: Fundamentalism, time and space in the Occupied Territories. Detroit, MI: Wayne State University Press.

Fowler, Carwyn, and Rhys Jones. 2005. "Environmentalism and nationalism in the UK." Environmental Politics 14 (4): 541-545.

Frank, David John. 1997. "Science, Nature, and the Globalization of the Environment, 18701990." Social Forces 76 (2): 409-435.

Frank, David John, Ann Hironaka, and Evan Schfer. 2000. "The nation-state and the natural environment over the twentieth century." American Sociological Review 65 (1): 96-116.

Galai, Yoav. 2017. "Narratives of redemption: The international meaning of afforestation in the Israeli Negev." International Political Sociology 11 (3): 273-291.

Goodland, Robert. 1995. "The concept of environmental sustainability." Annual Review of Ecological Systems 26: 1-24.

Gorski, Philip S. 2017. American covenant: A history of civil religion from the Puritans to the present. Princeton, NJ: Princeton Univ. Press.

Gorski, Philip S., and William McMillan. 2012. "Barack Obama and American exceptionalisms." The Review of Faith \& International Affairs 10 (2): 41-50.

Greenspan, Itay, Femida Handy, and Tally Katz-Gerro. 2012. "Environmental philanthropy: Is it similar to other types of environmental behavior?" Organization \& Environment 25 (2): 111-130.

Greider, Thomas, and Lorraine Garkovich. 1994. "Landscapes: The social construction of nature and the environment." Rural Sociology 59 (1): 1-24.

Gupta, Akhil. 1998. Postcolonial developments: Agriculture in the making of modern India . Durham, NC: Duke University Press. 
Gutkowski, Natalia. 2018. "Governing through timescape: Israeli sustainable agriculture policy and the Palestinian-Arab citizens." International Journal of Middle East Studies 50 (3): 471-492.

Han, Iris. 2008. "The New Zionism [Hebrew]." Deshe Institute. Accessed December 24, 2016. http://www.deshe.org.il/?CategoryID=183\&ArticleID=193\&SearchParam=האן.

Holt, Flora Lu. 2005. "The catch-22 of conservation: Indigenous peoples, biologists, and cultural change ." Human Ecology 33 (2): 199-215.

Jasanoff, Sheila. 2007. Designs on nature: Science and democracy in Europe and the United States. Princeton, NJ: Princeton University Press.

Jerolmack, Colin. 2013. The Global Pigeon. Chicago and London: Univ. of Chicago Press.

Jerolmack, Colin, and Shamus Khan. 2014. "Talk is cheap: Ethnography and the attitudinal fallacy." Sociological Methods \& Research 43 (2): 178-209.

Kern, Thomas. 2010. "Translating Global Values into National Contexts: The Rise of Environmentalism in South Korea." International Sociology 25 (6): 869-896.

Kessler, Anna, John R. Parkins, and Emily Huddart Kennedy. 2016. "Environmental harm and "the good farmer": Conceptualizing discourses of environmental sustainability in the beef industry." Rural Sociology 81 (2): 172-193.

Lamont, Michèle. 2012. "Toward a Comparative Sociology of Valuation and Evaluation." Annual Review of Sociology 38: 201-221.

Lamont, Michèle, and Ann Swidler. 2014. "Methodological pluralism and the possibilities and limits of interviewing ." Qualitative Sociology 37 (2): 153-171.

Lavie, Aviv. 2008. "True Zionism is Green Zionism [Hebrew]." NRG. September 21. Accessed December 25, 2016. http://www.nrg.co.il/online/1/ART1/789/818.html.

Longhofer, Wesley, and Evan Schofer. 2010. "National and global origins of environmental association." American Sociological Review 75 (4): 505-533.

Lynch, Michael E. 1988. "Sacrifice and the transformation of the animal body into a scientific object: Laboratory culture and ritual practice in the neurosciences." Social Studies of Science 18 (2): 265-289.

McKee, Emily. 2016. Dwelling in conflict: Negev landscapes and the boundaries of belonging. Palo Alto, CA: Stanford University Press.

Mertig, Angela G., and Riley E. Dunlap. 2009. "Environmentalism, new social movements, and the new class: A cross-national investigation." Rural Sociology 66 (1): 113-136.

Muehlmann, Shaylih. 2012. "Rhizomes and other uncountables: The malaise of enumeration in Mexico's Colorado River Delta ." American Ethnologist 39 (2): 339-353.

Mukerji, Chandra. 1997. Territorial ambitions and the gardens of Versailles. Cambridge: Cambridge University Press.

Norgaard, Kari Marie. 2011. Living in denial: Climate change, emotions, and everyday life. Cambridge, MA: MIT Press. 
Orenstein, Daniel E., Alon Tal, and Char Miller, . 2013. Between ruin and restoration: An environmental history of Israel. Pttsburgh, PA: University of Pittsburgh Press.

Orenstein, Daniel E., Leiwen Jiang, and Stephen P. Hamburg. 2011. "An elephant in the planning room: Political demography and its influence on sustainable land-use planning in drylands." Journal of Arid Environments 75 (6): 596-611.

Pampel, Fred C., and Lori M. Hunter. 2012. "Cohort change, diffusion, and support for environmental spending in the United States." American Journal of Sociology 118 (2): 420-448.

Pugh, Allison J. 2013. "What good are interviews for thinking about culture? Demystifying interpretive analysis." American Journal of Cultural Sociology 1 (1): 42-68.

Pyne, Stephen J. 1998. How the canyon became grand: A short history. New York: Viking.

Rabinowitz, Dan. 1992. "An Acre is an acre is an acre? Differentiated attitudes to social space and territory on the Jewish-Arab urban frontier in Israel." Urban Anthropology and Studies of Cultural Systems and World Economic Development 21 (1): 67-89.

Rabinowitz, Dan. 2003. "Borders and their discontents: Israel's Green Line, Arabness and unilateral separation." European Studies: A Journal of European Culture, History and Politics 19 (1): 217-231.

Ram, Uri. 1999. "The state of the nation: Contemporary challenges to Zionism in Israel." Constellations 6 (3): 325-228.

Randeria, Shalini. 2007. "Global designs and local lifeworlds: Colonial legacies of conservation, disenfranchisement and environmental governance in postcolonial India." Interventions 9 (1): $12-30$.

Rudel, Thomas K. 2013. Defensive environmentalists and the dynamics of global reform. New York: Cambridge University Press.

Sagy, Gonen, and Alon Tal. 2015. "Greening the curriculum: Current trends in environmental education in Israel's public schools." Israel Studies 20 (1): 57-85.

Schofer, Evan, and Ann Hironaka. 2005. "The effects of world society on environmental protection outcomes." Social Forces 84 (1): 25-47.

Schofer, Evan, and Francisco J. Granados. 2006. "Environmentalism, globalization and national economies, 1980-2000." Social Forces 85 (2): 965-991.

Shani, Liron. 2018a. "Liquid Distinctions: Negotiating Boundaries Between Agriculture and the Environment in the Israeli Desert." Anthropological Quarterly 91 (3): 1075-1103.

—. 2011. Nationalism between Land and Environment: The Conflict between "Oranges" and "Greens" over Settling in the East Lakhish Area. Baltimore, MD: The Univ. of Maryland Institute for Israel Studies Research Papers Series.

Shani, Liron. 2018b. "Of trees and people: The changing entanglement in the Israeli desert." Ethnos 83 (4): 624-644.

Shani, Liron. 2012. "Recipe for nature: The conflict between land and environmentalism: The struggle to establish a new settlement (Mirsham) the eastern area of Lachish [Hebrew]." Israeli Sociology 14 (1): 57-82. 
Shmueli, Deborah, Eran Feitelson, Benny Furst, and Iris Hann. 2015. "Scale and scope of environmental planning transformations: The Israeli case." Planning, Theory \& Practice 16 (3): 336-362.

Shorette, Kristen. 2012. "Outcomes of global environmentalism: Longitudinal and cross-national trends in chemical fertilizer and pesticide use." Social Forces 91 (1): 299-325.

Sutter, Paul. 2002. Driven wild: How the fight against automobiles launched the modern wilderness movement. Seattle, WA: University of Washington Press.

Tal, Alon. 2008. "Space matters: Historic drivers and turning points in Israel's open space protection policy." Israel Studies 13 (1): 119-151.

Tal, Alon, Shira Leon-Zchout, Itay Greenspan, Liat Oshry, and Shira Akov. 2013. "Israel's environmental movement: Strategic challenges." Environmental Politics 22 (5): 779-791.

Vasi, Ion Bogdan, and Brayden G. King. 2012. "Social movements, risk perceptions, and economic outcomes: The effect of primary and secondary stakeholder activism on firms' perceived environmental risk and financial performance." American Sociological Review 77 (4): 573-596.

Walley, Christine J. 2004. Rough Waters: Nature and Development in an East African Marine Park. Princeton, N.J.: Princeton University Press.

West, Paige, James Igoe, and Dan Brockington. 2006. "Parks and peoples: The social impact of protected areas." Annual Review of Anthropology 35: 251-277.

Yiftachel, Oren. 2002. "Territory as the kernel of the nation: Space, time and nationalism in Israel/Palestine." Geopolitics 7 (2): 215-248. 
Table 1 - Comparison of green and settler activists

\begin{tabular}{|l|l|l|}
\hline & Green activists & Settlers \\
\hline Mode of preserving nature & Nonintervention & Intervention \\
\hline Key practices in relation to & $\begin{array}{l}\text { Legal/bureaucratic action } \\
\text { Field surveys } \\
\text { Ecological analyses }\end{array}$ & $\begin{array}{l}\text { Building settlements } \\
\text { Hiking } \\
\text { Tree planting }\end{array}$ \\
\hline View of Zionism & $\begin{array}{l}\text { Zionism should be } \\
\text { reimagined in sustainable } \\
\text { terms ("New/Green } \\
\text { Zionism") } \\
\text { Protection of Israeli } \\
\text { landscape for future } \\
\text { generations }\end{array}$ & $\begin{array}{l}\text { Traditional ruralist Zionism } \\
\text { should be revived and } \\
\text { enhanced ("Real Zionism") }\end{array}$ \\
\hline View of settlement & $\begin{array}{l}\text { Acknowledgment of past } \\
\text { importance, but objection to } \\
\text { new settlements }\end{array}$ & $\begin{array}{l}\text { Ensuring Jewish presence in } \\
\text { all parts of Israel-Palestine } \\
\text { land and to nationalize it }\end{array}$ \\
\hline View of the Lachish region & $\begin{array}{l}\text { Open space, biodiversity } \\
\text { Ecological corridor }\end{array}$ & $\begin{array}{l}\text { New frontier for settling } \\
\text { Wilderness }\end{array}$ \\
\hline Self-perception & Apolitical & Apolitical \\
\hline Opposite-group perception & $\begin{array}{l}\text { Motivated solely by wish to } \\
\text { create new settlements }\end{array}$ & $\begin{array}{l}\text { Motivated by post-Zionist } \\
\text { hatred of settlements }\end{array}$ \\
\hline $\begin{array}{l}\text { Desired outcome for Gaza } \\
\text { evictees }\end{array}$ & $\begin{array}{l}\text { Resettlement in existing cities } \\
\text { and townships }\end{array}$ & $\begin{array}{l}\text { Establishment of new } \\
\text { settlements }\end{array}$ \\
\hline
\end{tabular}


Figure 1 - Location of the proposed settlement, to the south west of the Palestinian city of Hebron. Dashed line represents the 1949 Armistice Agreement line (the "Green Line") that served as the international border until 1967. Areas to the east of the line are the Occupied Palestinian Territories.

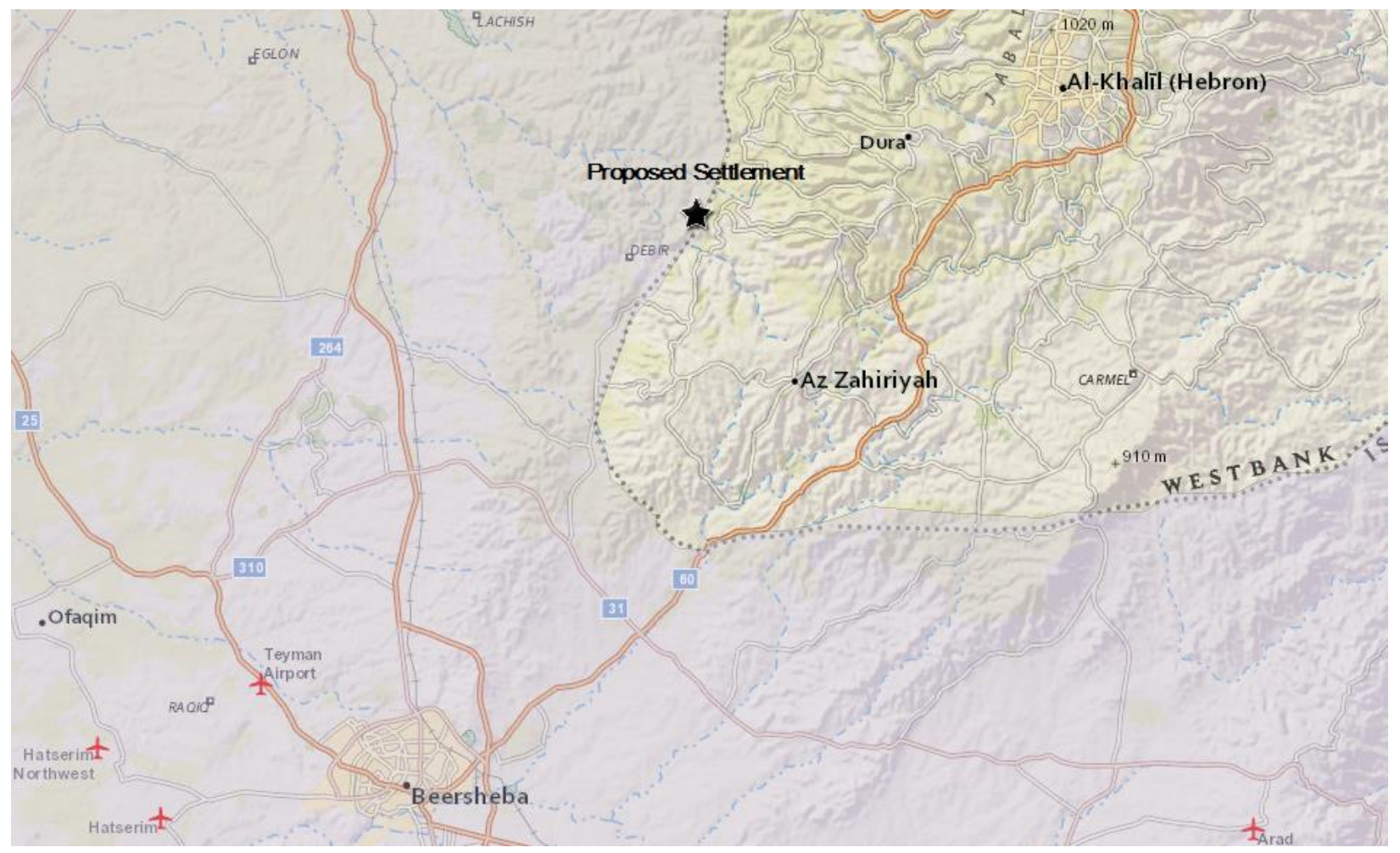


Online Appendix 1 - Quoted interviewee pseudonyms and background information

\begin{tabular}{|l|l|l|c|c|l|}
\hline & Pseudonym & Group & $\begin{array}{l}\text { Age at time of } \\
\text { interview }\end{array}$ & Gender & Official role / Occupation \\
\hline 1 & Adva & Settlers & 22 & F & Homemaker \\
\hline 2 & Amit & Green activists & 54 & M & Environmental studies professor \\
\hline 3 & Ariel & Settlers & 28 & M & Contractor, member of the Settlers' Committee \\
\hline 4 & Dror & Settlers & 42 & M & Political activist \\
\hline 5 & Hedva & Settlers & 23 & F & Social Worker \\
\hline 6 & Liat & Green activists & 30 & F & Environmentalist NGO staff member \\
\hline 7 & Nadav & Green activists & 42 & M & Senior member of environmental organization in southern Israel \\
\hline 8 & Na'ama & Green activists & 26 & F & Law student and volunteer in an environmental organization \\
\hline 9 & Nirit & Green activists & 34 & F & Planner in one of the environmental NGO \\
\hline 10 & Shmulik & Settlers & 35 & M & Head of the settlers' committee \\
\hline 11 & Eli & Settlers & 31 & M & Educator, member of the Settlers' Committee \\
\hline 12 & Shlomo & Settlers & 64 & M & Local politician \\
\hline 13 & Udi & Settlers & 23 & M & Educator \\
\hline 14 & Yehonatan & Green activists & 26 & M & Ecology Science student and environmental activist \\
\hline
\end{tabular}

